Journal of Al Azhar University Engineering Sector

Vol. 13 , No. 48 , July $2018,823-833$

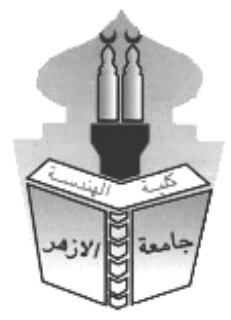

\title{
"EFFECT OF SHEAR CONNECTORS DISTRIBUTION AND REINFORCEMENT LAYOUT AT GROUTING POCKETS ON THE CONNECTION BETWEEN PRE- CAST CONCRETE GIRDERS AND PRE-CAST DECK PANELS"
}

\author{
Khaled Mohammed Hilal ${ }^{1}$, Amr Hussein Zaher ${ }^{1}$ and Hussein Salah Marzouk Youssef ${ }^{2}$ \\ ${ }^{1}$ Concrete Structures, Structural Engineering Department, Ain Shams University. \\ ${ }^{2}$ Civil Engineering Department Faculty of Engineering - Helwan University.
}

\begin{abstract}
Precast concrete decks have begun to revolutionize the bridge design industry due to their rapid constructability, reduction in overall mobilization and high quality control. According to international codes it was found that distribution of shear connectors is one of the most important factors that has an effect on the capacity of the connection. Previous research and design guidelines suggest the use of two different approaches to quantify the required interfacial shear strength, namely based on the maximum compressive forces in the flange at mid-span or the maximum shear flow at the supports. The research objectives can be summarized in evaluating the structural behavior and load carrying capacity experimentally and analytically for precast girders and precast slabs connected through shear connectors in grouting pockets in the case of regular or concentrated shear connectors distribution at support. In addition the effect of adding horizontal rebars around the grouting pockets in the deck slab was determined. Seven composite RC T-beams with $2.00 \mathrm{~m}$ span were tested under static loading conditions.
\end{abstract}

\section{INTRODUCTION}

Several precast elements are available to meet with all construction requirements. It is often preferable to transport beams and deck slabs separately to reduce the weight of each element. The interfacial shear transfer between the top slab and the supporting beams is of great significance to the overall deck load carrying capacity and performance. To give an understanding of the behavior of precast beam connected to precast panels by using shear connectors a brief review of previous research work can be summarized as follows:

\section{1- Mast (1958)}

Mast (1958) was the first to introduce a linear shear friction equation, and was later revised by Birkeland and Anderson (1960). The equation as introduced by Mast is as follows:

Where,

$$
v_{\mathrm{n}}=\rho . \mathrm{fy} \cdot \mu \quad(\mathrm{MPa})
$$

$v_{\mathrm{n}} \quad=$ ultimate horizontal shear strength, $\rho \mathrm{fy}=$ clamping stress, $\mu=$ empirical coefficient of friction

The equation (1) is simple but is very conservative for law clamping stresses and unsafe for high clamping stresses (Loov and Patnaik-1994). 


\section{2- Birkeland (1966)}

Birkeland (1966) was the first to introduce a non-linear function for the ultimate shear capacity of the interface. Birkeland's equation only incorporated a factor times the clamping stress as shown below:

2 ) $v_{n}=2.78 \sqrt{ }(\rho v$ fy $) \quad(\mathrm{MPa})$

Nothing in Birkeland's equation accounted for varying surface treatments or concrete strengths.

\section{3- Shaikh (1978)}

Shaikh (1978) proposed a modification to the shear-friction provisions of ACI. The proposed equation can be simplified to the following:

$v_{u}=\square . \rho_{v . .} f_{y} . \mu e$

(MPa)

Where,

$\mu_{e}=\frac{6.9 \lambda^{2}}{v_{u}}$

(MPa)

In this simplified equation, $1.0 \lambda$ has been substituted for $\mu$ and $\lambda$ is a constant used to account for the effect of concrete density.

$\lambda=1.0$ for normal weight concrete, $\lambda=0.85$ for sand-lightweight concrete, $\lambda=$ 0.75 for all-lightweight concrete, the strength reduction factor for shear was $\square \square=$ 0.85 .

\section{4- $\operatorname{Loov}(1978)$}

Loov (1978) was the first to introduce the influence of concrete strength into the horizontal shear strength equation. Below is the equation that was presented by Loov:

$$
v_{\mathrm{n}}=\mathrm{k} \sqrt{\rho_{v} \mathrm{f}_{y} \mathrm{f}^{\prime}{ }^{\prime}}
$$

$(\mathrm{MPa})$

Where,

$\mathrm{k}=$ constant ( 0.5 was suggested for an initially un-cracked interface).

$\mathrm{f}^{\prime} \mathrm{c}=$ the concrete strength in $(\mathrm{MPa})$.

\section{5- Patnaik (2001):}

Patnaik recommended the use of the following equations.

$v_{u}=(0.6+\square$.fy $) \leq 0.2 \mathrm{f}^{\prime} \mathrm{c}$ and 5.5

(MPa)

$6)$

$v_{u}=0$ for $\square$.fy $\leq 0.35$

( 7 )

Patnaik states that it is possible to obtain some nominal shear strength from a smooth interface with no reinforcing, but for design this is not recommended.

\section{Experimental program}

The experimental program comprised a total of seven medium-scale reinforced concrete beam specimens tested up to failure at the Reinforced Concrete Laboratory of the Structural Department of the Faculty of Engineering at Ain Shams University. The seven beam specimens were tested to investigate the modes of failure, the ultimate load carrying capacity and the behavior of the connection between pre-cast beams connected to pre-cast deck slab and its influence on the beam action mechanism. The deformation, crack pattern, strain of main reinforcement and strain of shear connectors were monitored and recorded during the tests. All specimens with overall dimensions of $450 \mathrm{~mm}$ width, $80 \mathrm{~mm}$ thickness for the flange, $150 \mathrm{~mm}$ width and $300 \mathrm{~mm}$ depth for the web with span $2000 \mathrm{~mm}$. 
EFFECT OF SHEAR CONNECTORS DISTRIBUTION AND REINFORCEMENT LAYOUT AT GROUTING POCKETS ON THE CONNECTION BETWEEN PRE-CAST CONCRETE GIRDERS AND PRE-CAST DECK PANELS"

One of the specimens (B1) was a full-depth monolithic T-section as a control specimens as shown in Fig (1).

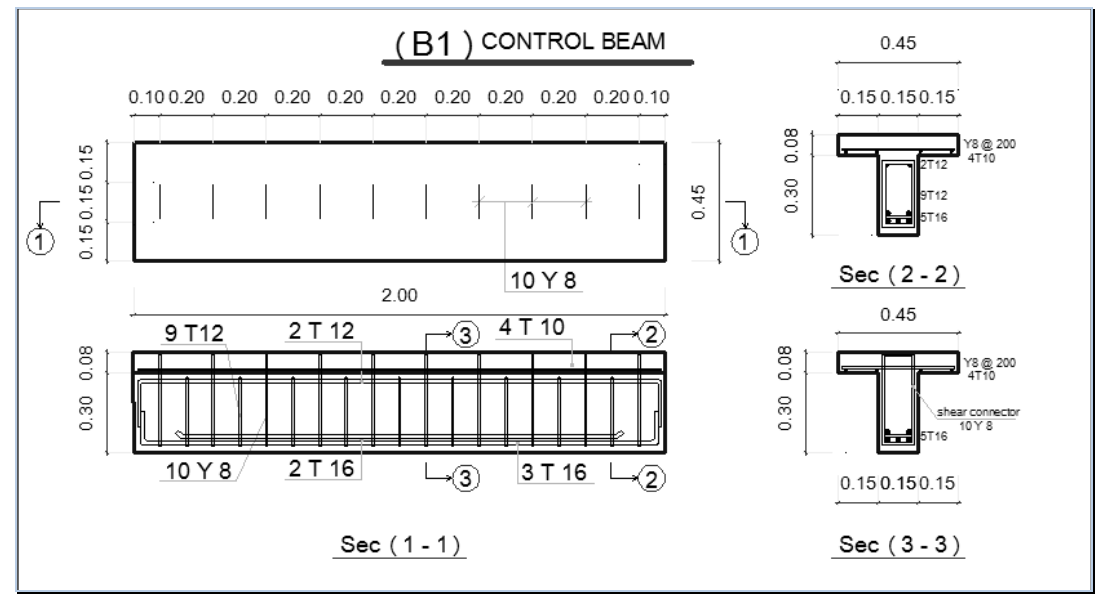

Fig 1: Specimen (B1)-Control specimen.

Other six specimens (B2 to B7) were not poured monolithically. The following tables presents the properties of the tested beams:

Table 1: Specific parameters for the tested beam specimens.

\begin{tabular}{|c|c|c|c|c|}
\hline $\begin{array}{c}\text { Beam } \\
\text { specimen } \\
\text { NO. }\end{array}$ & $\begin{array}{c}\text { Type of connection between } \\
\text { the beam and the slab panel }\end{array}$ & $\begin{array}{c}\text { Shear connectors' } \\
\text { distribution } \\
\text { B1 }\end{array}$ & $\begin{array}{c}\text { Adding } \\
\text { at the } \\
\text { interface }\end{array}$ & $\begin{array}{c}\text { Adding } \\
\text { horizontal } \\
\text { rebar }\end{array}$ \\
\hline B2 & $\begin{array}{c}\text { Grouted pockets with shear } \\
\text { connectors }\end{array}$ & $\begin{array}{c}\text { Uniform Along } \\
\text { beam span } \\
\text { beam span }\end{array}$ & No & N.A \\
\hline B3 & $\begin{array}{c}\text { Grouted pockets with shear } \\
\text { connectors }\end{array}$ & $\begin{array}{c}\text { Uniform Along } \\
\text { beam span }\end{array}$ & YES & NO \\
\hline B4 & $\begin{array}{c}\text { Grouted pockets with shear } \\
\text { connectors }\end{array}$ & $\begin{array}{c}\text { Concentrated at } \\
\text { beam edges }\end{array}$ & NO & NO \\
\hline B5 & $\begin{array}{c}\text { Grouted pockets with shear } \\
\text { connectors }\end{array}$ & $\begin{array}{c}\text { Concentrated at } \\
\text { beam edges }\end{array}$ & YES & NO \\
\hline B6 & $\begin{array}{c}\text { Grouted pockets with shear } \\
\text { connectors }\end{array}$ & $\begin{array}{c}\text { Uniform Along } \\
\text { beam span }\end{array}$ & NO & NO \\
\hline B7 & $\begin{array}{c}\text { Grouted pockets with shear } \\
\text { connectors }\end{array}$ & $\begin{array}{c}\text { Uniform Along } \\
\text { beam span }\end{array}$ & YES & YES \\
\hline
\end{tabular}

Table 2: The properties of the tested beams.

\begin{tabular}{|c|c|c|c|c|c|c|c|}
\hline $\begin{array}{c}\text { Beam } \\
\text { Specimen }\end{array}$ & $\begin{array}{c}\mathbf{f}_{\mathrm{cu}} \\
(\mathrm{MPa})\end{array}$ & $\begin{array}{l}\text { Beam } \\
\text { L X t } \\
(\mathrm{mm})\end{array}$ & $\begin{array}{c}\text { Interface } \\
\text { Area } \\
\left(\mathrm{mm}^{2}\right)\end{array}$ & $\begin{array}{l}\text { Main } \\
\text { RFT }\end{array}$ & \multicolumn{2}{|c|}{$\begin{array}{l}\text { Connectors Area } \\
\quad\left(\mathrm{mm}^{2}\right)\end{array}$} & $\% \rho$ \\
\hline B1 & 37.4 & $2000 \times 380$ & 30000 & $5 \varphi 16$ & 1008 & $10 \mathrm{Y} 8$ & 0.33 \\
\hline B2 & 37.4 & $2000 \times 380$ & 30000 & $5 \varphi 16$ & 1008 & $10 \mathrm{Y} 8$ & 0.33 \\
\hline B3 & 37.4 & $2000 \times 380$ & 30000 & $5 \varphi 16$ & 1008 & $10 \mathrm{Y} 8$ & 0.33 \\
\hline B4 & 37.4 & $2000 \times 380$ & 30000 & $5 \varphi 16$ & 1008 & $10 \mathrm{Y} 8$ & 0.33 \\
\hline B5 & 37.4 & $2000 \times 380$ & 30000 & $5 \varphi 16$ & 1008 & $10 \mathrm{Y} 8$ & 0.33 \\
\hline B6 & 37.4 & $2000 \times 380$ & 30000 & $5 \varphi 16$ & 1570 & $10 \varphi 10$ & 0.52 \\
\hline B7 & 37.4 & $2000 \times 380$ & 30000 & $5 \varphi 16$ & 1570 & $10 \varphi 10$ & 0.52 \\
\hline
\end{tabular}


EFFECT OF SHEAR CONNECTORS DISTRIBUTION AND REINFORCEMENT LAYOUT AT GROUTING POCKETS ON THE CONNECTION BETWEEN PRE-CAST CONCRETE GIRDERS AND PRE-CAST DECK PANELS"

The key parameters considered in experimental program were the following:

a- different patterns of shear connector's distribution along the beam span.

b- adding grout at connecting surface.

c- adding horizontal rebar at grouting pockets.

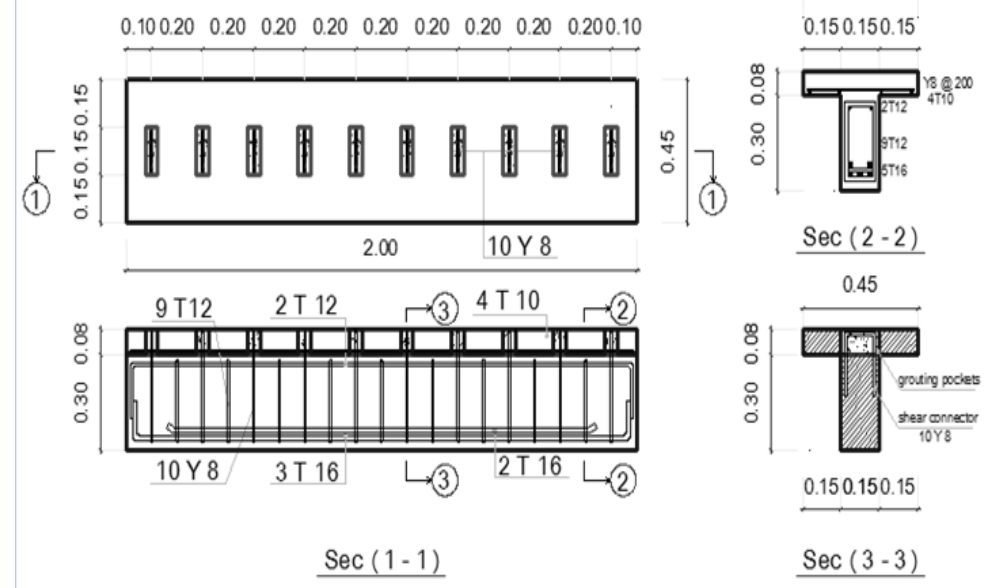

Fig 2: uniform distribution of shear connectors along beam span.

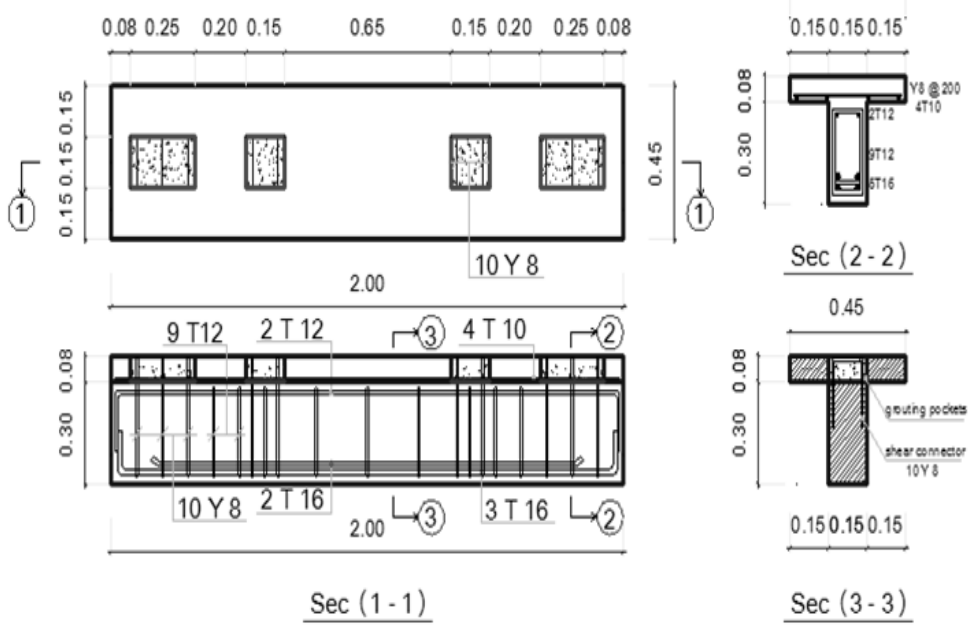

Fig 3: concentration of shear connectors at beam edges.

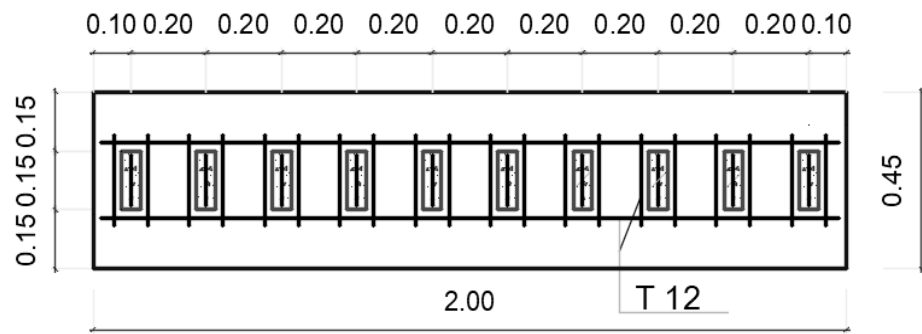

Fig 4: horizontal rebar at grouting pockets. 
EFFECT OF SHEAR CONNECTORS DISTRIBUTION AND REINFORCEMENT LAYOUT AT GROUTING POCKETS ON THE CONNECTION BETWEEN PRE-CAST CONCRETE GIRDERS AND PRE-CAST DECK PANELS"

The specimens were fabricated in two stages; the first stage included casting of one reinforced concrete T-section beam specimen (control specimen) and six R-section beam specimens with different shear connectors' distribution and also included casting of the slab panels for the six specimens with different pocket distributions. The second stage included the application of the grout in the pockets and the grout resin at the interfacial surface. As shown in Fig (5)
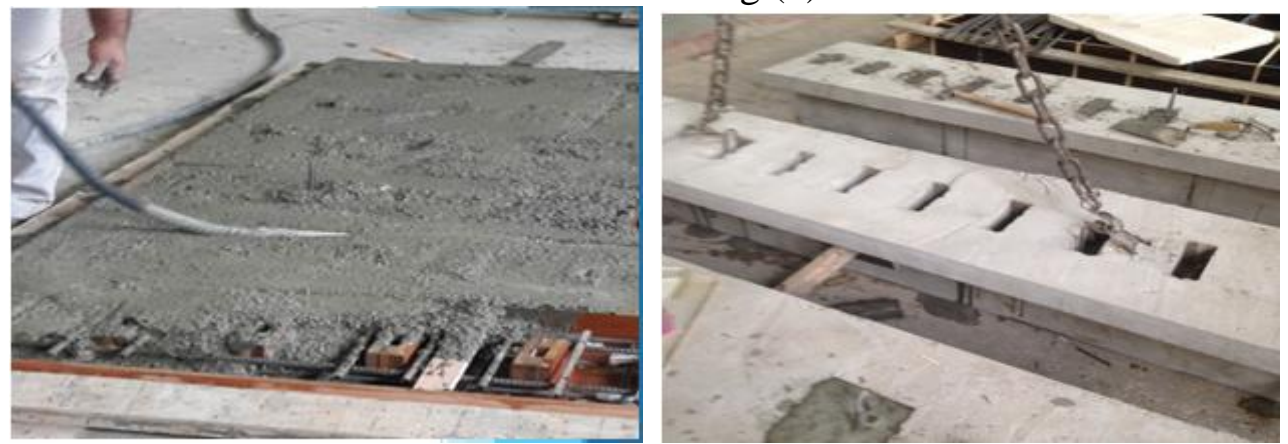

Fig 5: Fabrication of the tested specimens.

The beams were tested under monotonically increasing vertical load using a hydraulic Jack of $1000-\mathrm{kN}$ capacity. The specimens were instrumented to record deflection, strain of longitudinal steel reinforcement, as well as strain of the shear connectors. Instrumentation of the beam specimens included Linear Voltage Displacement Transducers (LVDTs) for vertical deflection and horizontal slip between the web and the flange measurements, strain gauges were used for steel strain as shown in the following Figures.
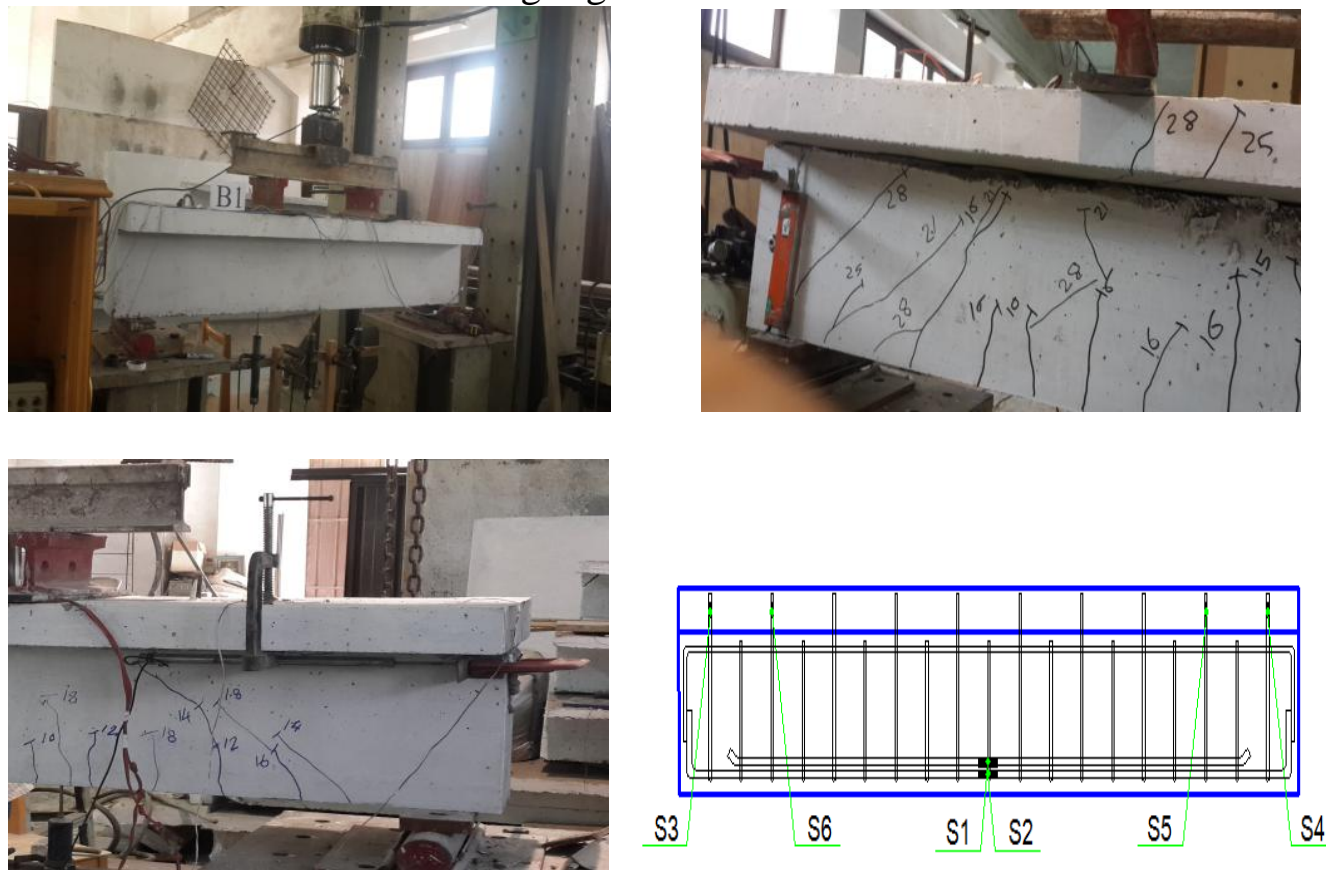

Fig 6: Detailed description of the instrumentation.

\section{Test Results}

All the beams were tested up to failure. The failure mode for all specimens was the shear mode as shown in figure 7. 

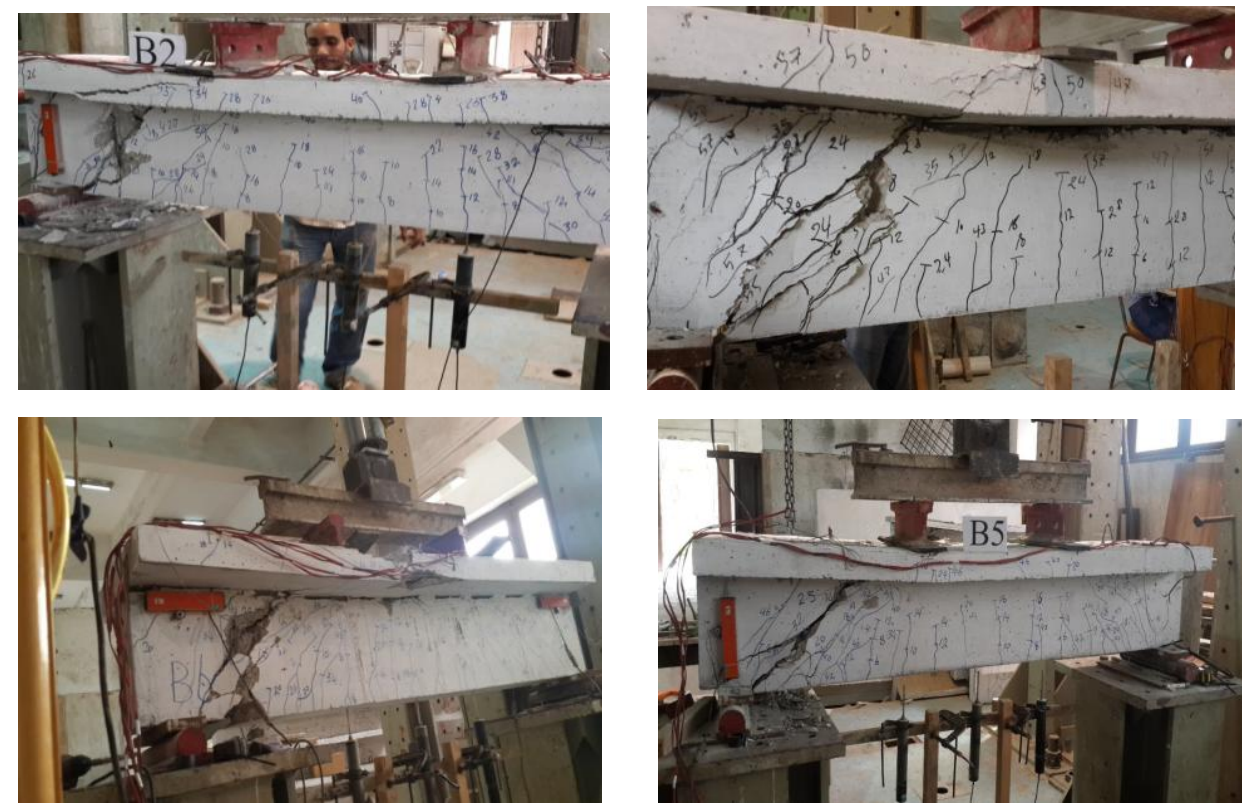

Fig 7: Failure mode for all beam specimens

The failure loads for all the tested specimens and the deflection at failure load for all the tested specimens are summarized in Fig 8 and Fig 9. Fig 8 shows that the failure load for all specimens were similar except B7. The average of the failure load for B2 and B3 was $478 \mathrm{kN}$ which equal to $98 \%$ of failure load of control beam. The average of the failure load for B4 and B5 was $455 \mathrm{kN}$ which equal to $94 \%$ of failure load for control beam. The increasing of shear connectors ratio only development the capacity of the specimen by $2 \%$ as occurred in specimen B6. While with adding horizontal reabers around the grouting pockets the specimen capacity was increased by $20 \%$ as occurred in specimen B7.

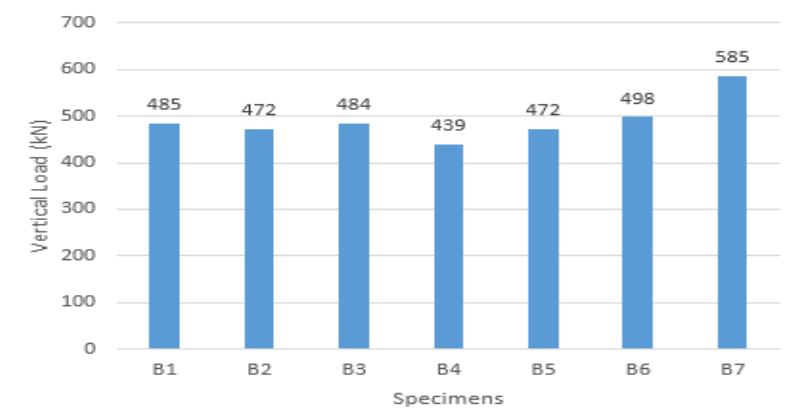

Fig 8: Failure loads for all beam specimens.

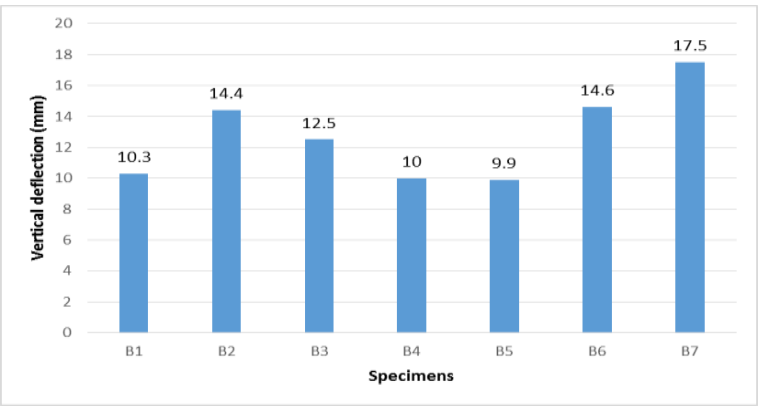

Fig 9: Vertical deflection at failure load for specimens B1 to B7. 


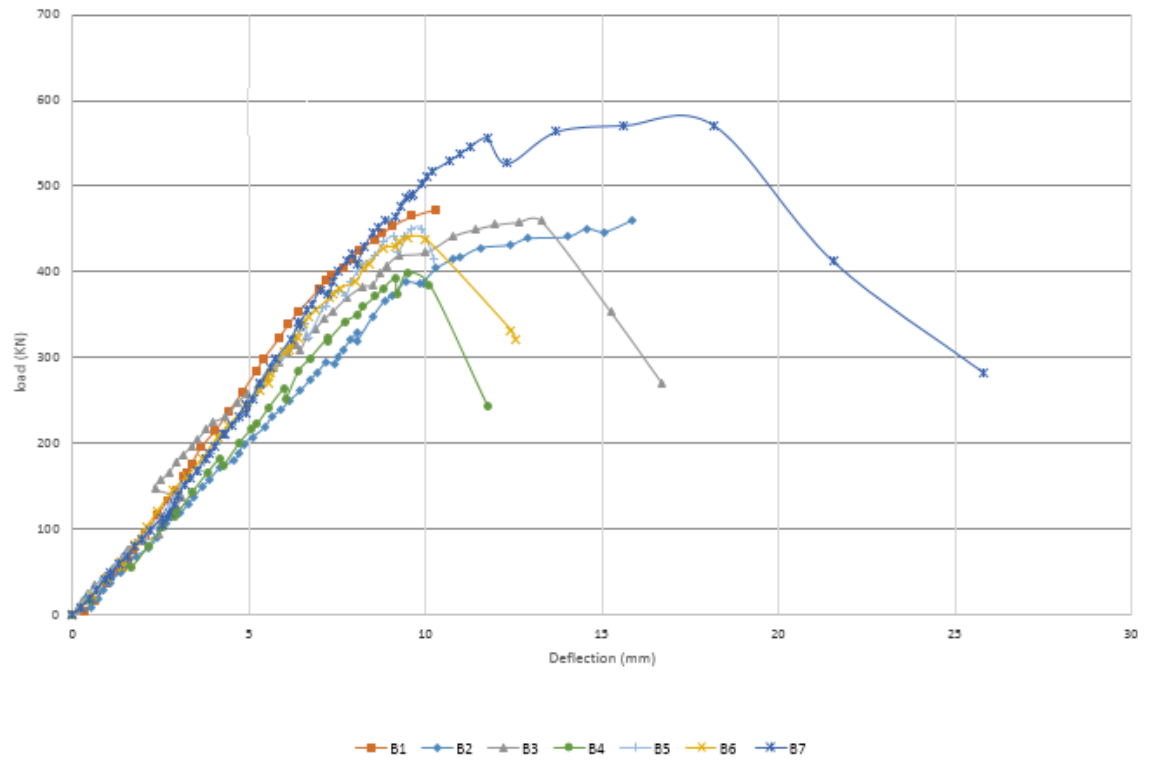

Fig 10: Vertical load - deflection for all specimens.

the average of the deflection for B2 and B3 were $13.4 \mathrm{~mm}$ which equal to $124 \%$ of the deflection of the control beam. the average of the deflection for B4 and B5 were $10 \mathrm{~mm}$ which equal to $103 \%$ of the deflection of the control beam. Deflection of B6 were $14.4 \mathrm{~mm}$ which equal to $139 \%$ of deflection for control beam. Deflection of B7 were $17.5 \mathrm{~mm}$ which equal to $166 \%$ of deflection for control beam. it can be noted that the uniform distribution of shear connectors increase the deflection of the beam which have a direct indication on beam ductility.

Strain in longitudinal steel.

The load - strain in longitudinal steel curves for all specimens are compared with control beam in Fig 11.

Fig 11: Load - Longitudinal tensile strain relationship for longitudinal steel reinforcement for all beams specimens.

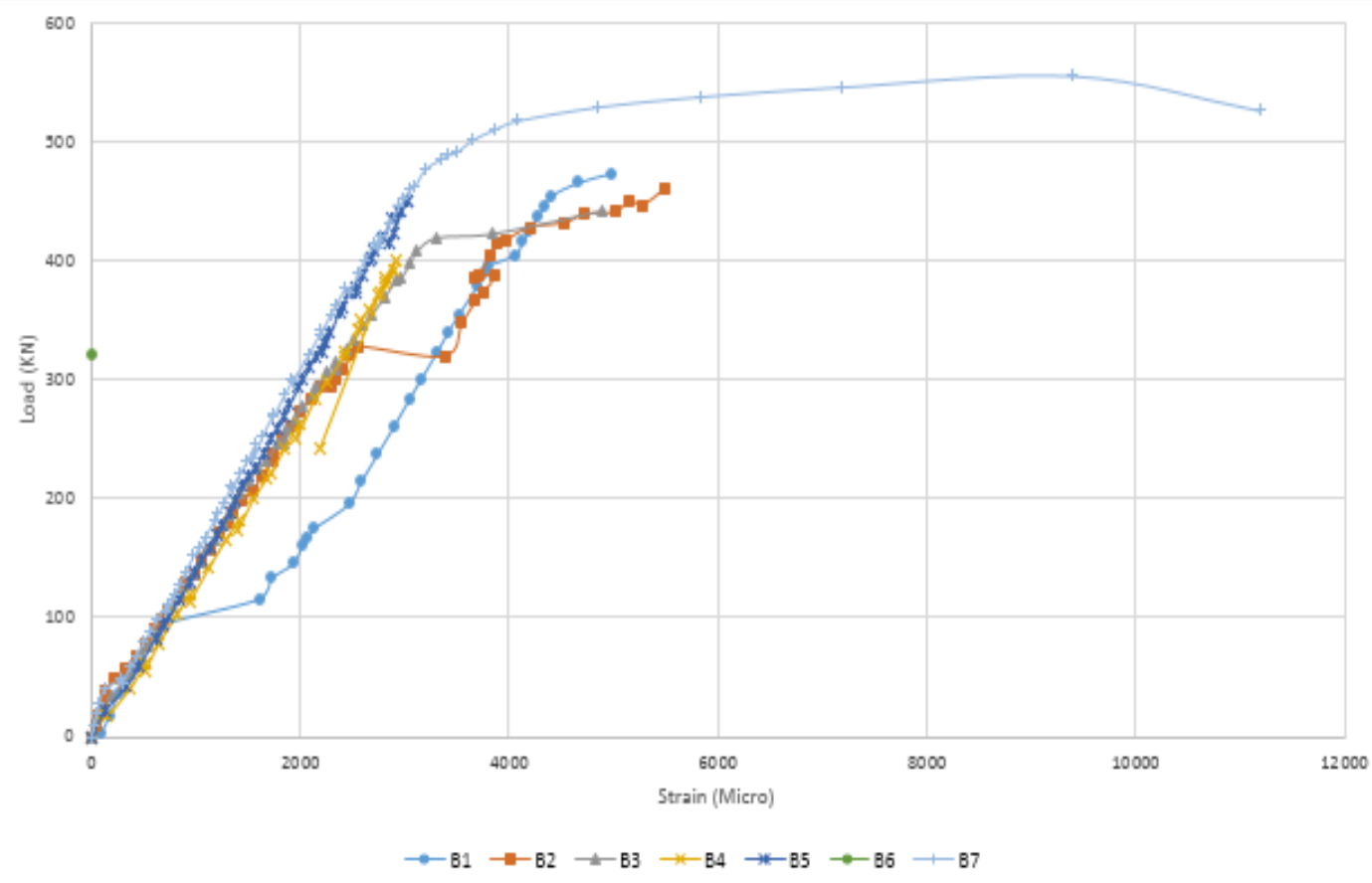


It can be noticed that the steel strain is almost the same for all beam specimens due to the same reinforcement ratio.

\section{Strain in shear connectors}

The steel strain was measured at 4 shear connectors near the support. The maximum measured strain for each beam is given in figure 12 .

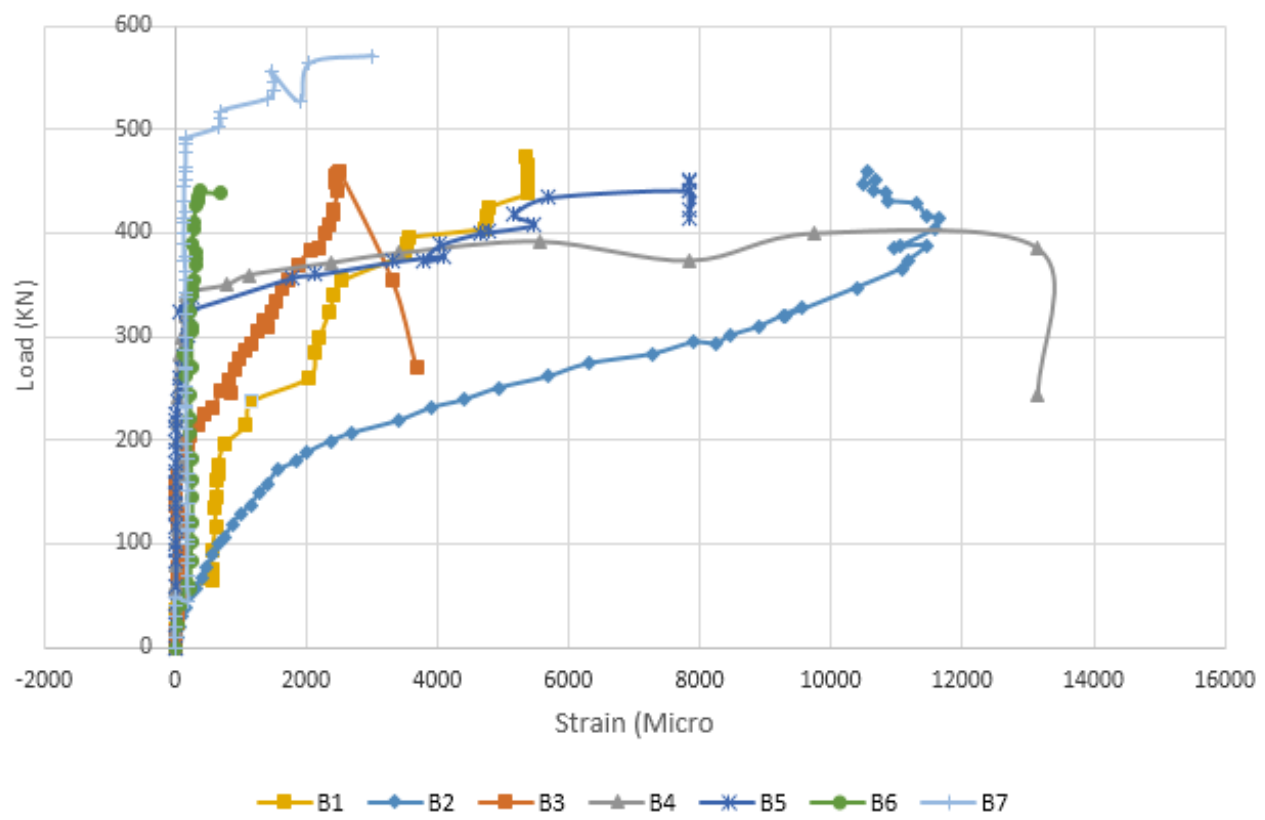

Fig 12: Load - strain in shear connectors relationship for all beams specimens.

\section{Sliding}

The value of sliding between the flange and the web at failure load for all specimens are compared in Fig 13.

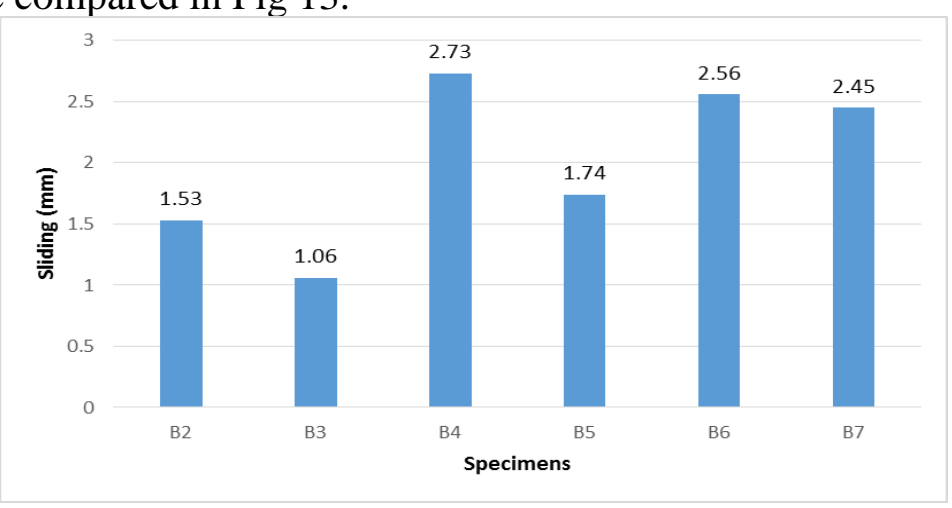

Fig 13: Horizontal sliding for specimens B2 to B7.

Fig 13 shows that the grout layer improves the connection between the web and the flange and resulting in less the sliding at failure. It also can be noted that the uniform distribution of the shear connectors decrease the sliding of the flange. First Crack at Interfacial Surface.

The loads causing the first visible crack at the interfacial surface are summarized in Fig 14. 


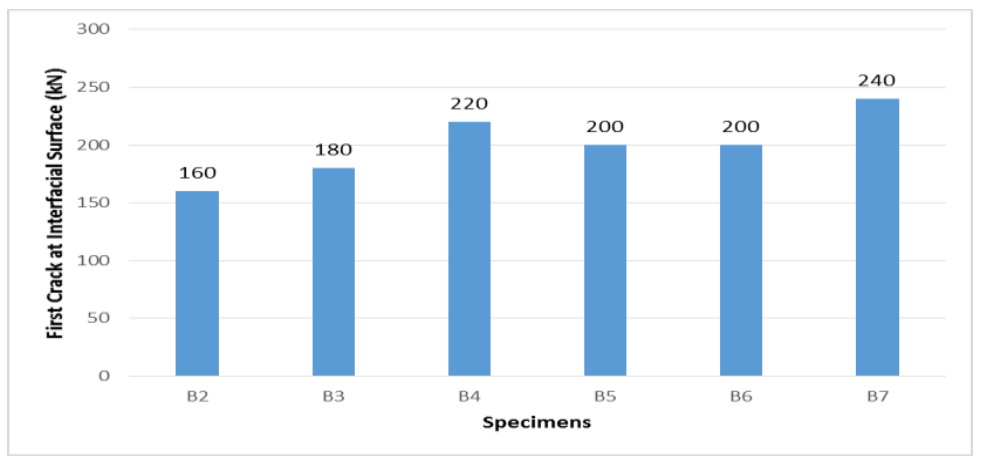

Fig 14: The load of the first crack at interfacial surface for specimens B2 to B7.

Fig 14 shows that the concentration of shear connectors at beam sides improves the connection between the web and the flange.

\section{First Crack at Grouting Pockets}

The loads causing the first visible crack at the grouting pockets are summarized in Fig 15.

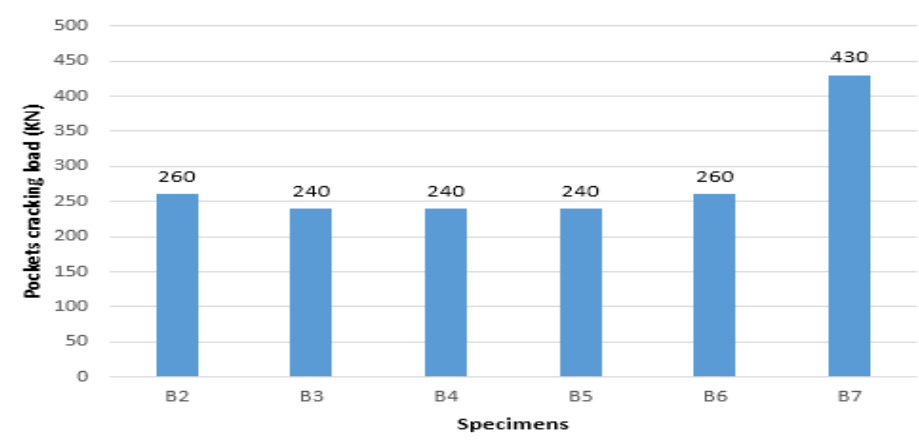

Fig 15: The load of the first crack at grouting pockets for specimens B2 to B7.

Fig 15 shows that adding horizontal rebars around the pockets increased the cracking load from $260 \mathrm{kN}$ to $430 \mathrm{kN}$ ( $1.65 \%$ ).

\section{Analytical work}

The theoretical horizontal shear stress was calculated by using self-developed spreadsheets the equation briefly described above. Table 3 shows the values of the experimental and the calculated horizontal shear stress for the six tested specimens from B2 to B7.

Table 3: Comparison between the experimental versus calculated horizontal shear stress for beam specimens $\mathrm{B} 2$ to $\mathrm{B} 7$.

\begin{tabular}{|c|c|c|c|c|c|c|c|c|}
\hline \multirow{3}{*}{$\begin{array}{c}\text { Beam } \\
\text { Specimen }\end{array}$} & \multirow{3}{*}{$\begin{array}{c}V_{\text {Exxper. }} \\
\text { (aspa) }\end{array}$} & \multicolumn{7}{|c|}{$V_{\text {usthea (MPRa) }}$} \\
\hline & & \multicolumn{5}{|c|}{ ACl-11.7 } & \multirow{2}{*}{ 堊 } & \multirow{2}{*}{ 离 } \\
\hline & & Mast & Birkeland & Shaikh & Loov & Walraven & & \\
\hline B2 & 3.32 & 1.16 & 2.99 & 2.6 & 3 & 3 & 3.5 & 1.4 \\
\hline B3 & 3.41 & 1.16 & 2.99 & 2.6 & 3 & 3 & 3.5 & 1.4 \\
\hline B4 & 3.09 & 1.16 & 2.99 & 2.6 & 3 & 3 & 3.5 & 1.4 \\
\hline B5 & 3.32 & 1.16 & 2.99 & 2.6 & 3 & 3 & 3.5 & 1.4 \\
\hline B6 & 3.51 & 2.94 & 4.77 & 4.2 & 4.8 & 6 & 6 & 3.5 \\
\hline B7 & 4.10 & 2.94 & 4.77 & 4.2 & 4.8 & 6 & 6 & 3.5 \\
\hline
\end{tabular}

Comparison between different analytical models based on experimental data 
A comparison can be made between the analytical models based on the experimental data as shown above. Table 4 shows the error \%, average and standard deviation $\%$ for the available analytical models and codes.

Table 4: Comparison between different analytical models.

\begin{tabular}{c|c|c|c}
\multirow{2}{*}{ Bean Specimen } & \multicolumn{3}{|c}{ Error\% $=\frac{v_{\text {theo. }}-v_{\text {Expr. }}}{v_{\text {Exper. }}}$} \\
\cline { 2 - 4 } & MAST & BIRKELAND & SHAIKH \\
\hline B2 & -65 & -10 & -22 \\
\hline B3 & -66 & -12 & -24 \\
\hline B4 & -62 & -03 & -16 \\
\hline B5 & -65 & -10 & -22 \\
\hline B6 & -16 & 36 & 20 \\
\hline B7 & -28 & 16 & 02 \\
\hline Average & -50 & 03 & -10 \\
\hline STD\% & 22.32 & 19.27 & 17.68
\end{tabular}

Table 4 (Cont.): Comparison between different analytical models.

\begin{tabular}{c|c|c|c|c}
\multirow{2}{*}{$\begin{array}{c}\text { Bean } \\
\text { Specimen }\end{array}$} & \multicolumn{5}{|c}{ Error\% $=\frac{v_{\text {theo }}-v_{\text {Expr. }} \%}{v_{\text {theo }}}$} \\
\cline { 2 - 5 } & Loov & Walaraven & $\begin{array}{c}\text { AASHTO } \\
\text { LRFD 2007 }\end{array}$ & ECP 2007-203 \\
\hline B2 & -10 & -10 & 05 & -58 \\
\hline B3 & -12 & -12 & 03 & -59 \\
\hline B4 & -03 & -03 & 13 & -55 \\
\hline B5 & -10 & -10 & 05 & -58 \\
\hline B6 & 37 & 71 & 71 & 00 \\
\hline B7 & 17 & 46 & 46 & -15 \\
\hline Average & 0.03 & 0.13 & 0.24 & -0.41 \\
\hline STD\% & 19.75 & 35.75 & 28.20 & 26.29
\end{tabular}

\section{CONCLUSIONS}

The present study investigated the horizontal shear transfer between precast beams and precast deck panels. The following points summarize the findings of this investigation:

1. The uniform shear connectors distribution along beam span (B2 and B3) achieved $98.5 \%$ from the capacity of the control beam specimen while specimens with a concentration of shear connectors at beam sides (B4 and B5) achieved $94 \%$ from the capacity of the control beam specimen.

2. The uniform distribution of shear connectors along beam span improve deflection behavior and the ductility of the beam.

3. Increasing the shear connectors ratio from $0.33 \%$ to $1.2 \%$ increase the capacity of beams by $14 \%$.

4. The groute layer at interface surface between flange and web had no significant effect on the full capacity and the ductility of the beam specimens and decrease the sliding values between the slab and the web.

5. With the same shear connectors ratio adding horizontal rebars around the grouting pockets in (B7) improves the capacity, deflection behavior and the ductility of beam.

6. Loov equation for estimation the shear stress had the nearest values to the experimental results. 


\section{REFERENCE}

1. Fatmir Menkulasi, (2002). "Horizontal Shear Connectors for Precast Prestressed Bridge Deck Panels ", faculty of the Virginia Polytechnic Institute and State University.

2. ACI Committee 318, Building Code Requirements for Reinforced Concrete (ACI 318-2008) and Commentary (ACI 318R-2008), American Concrete Institute.

3. BS 8110, (1997): "Structural use of Concrete - Part 1", Code of Practice for Design and Construction, Part 2, Code of Practice for Special Circumstances, British Standards Institute, London, 1997.

4. Robert E. Loov and Anil K. Patnaik,. "Horizontal Shear Strength of Composite Concrete Beams With a Rough Interface", PCI Journal.

5. Karim Atef (2012), " Behavior of Connections Between Precast High Performance Concrete Beams and Deck Slabs ", Ain Shams University.

6. DON P. SCHOLZ, (2007). "Recommendations For The Connection Between Full-Depth Precast Bridge Deck Panel Systems and Precast I-Beams.

7. AASHTO LRFD Bridge Design Specification, (2010), "America Association of State Highway and transportation officials".

8. L.A Clark, (1981). "Concrete Bridge Design to BS5400 Handbook".

9. E.C.P. 203, (2007) "Egyptian Code of Practice for Reinforced Concrete Constructions", Ministry of Development, New Communities, Housing and Utilities, National Housing and Building Research Center.

10. Moataz Awry, " Interfacial Shear Behavior of Composite Flanged Concrete Beams", Ain Shams University.

11. Mashour Ghoneim and Mahamoud El-Mihilmy, (2006). "Design of Reinforced Concrete Structures" Volume 1, Volume 2 and Volume 3, 1 st edition.

12. Joost Walraven. "Influence of concrete strength and load history on the shear friction capacity of concrete members", Darmstadt University of Technology.

13. Thimothy E.Banta, (February 2005), " Horizontal shear transfer between ultrahigh performance concrete and light weight concrete", Faculty of Virginia polytechnic institute and state university.

14. PCI Design Handbook, (2004). "Precast and Prestressed Concrete Handbook", 6 th edition.

15. Jonathan D. Kovach, (June 2008). "Horizontal shear capacity of composite concrete beams without interface ties", PCI / Pita research project.

16. Maria Lang, (September 2011), "Analysis of the AASHTO LRFD horizontal shear strength equation", Faculty of Virginia polytechnic institute and state university.

17. ALA"A ABDULAAL MAHMOUD, " Capacity of shear joint between reinforced concrete precast elements and reinforced concrete normal casting place elements", Al-AZHAR University

18. Yoshiki Tanaka and Sadaaki Nakamura, (2010), "Effectiveness of cohesion $\mathrm{n}$ on horizontal shear transfer for composite prestressed concrete girder", Public work research institute and Japan prestressed concrete contractors association.

19. Ahmad Shaban, (2012), "Effect of interface position and percentage of shear connectors on the behavior of one-way composite pre-slabs", Journal of American science.

20. Joost Walraven, " Influence of concrete strength and load history on the shear friction capacity of concrete members", Delft University of technology, Netherlan. 